\title{
Fas ligand-mediated mechanisms are involved in autoimmune destruction of islet beta cells in non-obese diabetic mice
}

\author{
W. L Suarez-Pinzon ${ }^{1}$, R.F.Power ${ }^{2}$, A. Rabinovitch ${ }^{1}$ \\ ${ }^{1}$ Department of Medicine, University of Alberta, Edmonton, Alberta, Canada \\ ${ }^{2}$ Department of Laboratory Medicine and Pathology, University of Alberta, Edmonton, Alberta, Canada
}

\begin{abstract}
Aims/hypothesis. A mechanism implicated in pancreatic islet beta-cell destruction in autoimmune diabetes is the binding of the Fas ligand (FasL) on T cells to Fas receptors on beta cells, causing their destruction. Evidence for this mechanism is, however, controversial. The aim of this study was to find whether the Fas ligand contributes to beta-cell death in autoimmune diabetes.

Methods. We transplanted syngeneic islets under the renal capsule in non-obese diabetic (NOD) mice and treated the mice with a neutralizing monoclonal antibody to the Fas ligand. Survival of beta cells in islet grafts and phenotypes of graft-infiltrating cells were investigated.

Results. We found $58 \%$ (7 of 12) of mice treated with anti-Fas ligand antibody were normoglycaemic at 30 days after islet transplantation compared with
\end{abstract}

none $(0$ of 9$)$ of the mice treated with control antibody. Immunohistochemical analysis of islet grafts showed that infiltration of leucocytes $\left(\mathrm{CD}^{+}{ }^{+} \mathrm{T}\right.$ cells, $\mathrm{CD}^{+} \mathrm{T}$ cells, macrophages and neutrophils) and apoptosis of beta cells in the grafts was significantly decreased in mice treated with anti-Fas ligand antibody. Expression of proinflammatory cytokines (interleukin 1 alpha, tumour necrosis factor alpha and interferon gamma) was not different in islet grafts of mice treated with anti-Fas ligand and control antibodies.

Conclusion/interpretation. These findings indicate that Fas ligand-mediated mechanisms play a major part in promoting leucocytic infiltration of islets and beta-cell destruction in autoimmune diabetes. [Diabetologia (2000) 43: 1149-1156]

Keywords Type I diabetes, NOD mice, beta cells, islet transplantation, Fas ligand, apoptosis.
A variety of immune system cells, including macrophages, $\mathrm{CD}^{+}{ }^{+} \mathrm{T}$ cells and $\mathrm{CD} 8^{+} \mathrm{T}$ cells have been implicated as mediators of pancreatic islet beta-cell destruction in Type I (insulin-dependent) diabetes mellitus. One of the mechanisms of T-cell cytotoxicity is a receptor-mediated mechanism in which Fas ligand (FasL) (CD95L) molecules on the surface or released

Received: 31 March 2000 and in revised form: 5 June 2000

Corresponding author: A. Rabinovitch, MD, 430 Heritage Medical Research Centre, University of Alberta, Edmonton, Alberta, Canada T6G 2S2

Abbreviations: NOD, non-obese diabetic; FasL, Fas ligand; IL$1 \alpha$, interleukin 1 alpha; IFN- $\gamma$, interferon gamma; FITC, fluorescein isothiocyanate; $\mathrm{mAB}$, monoclonal antibody. from T cells bind to Fas (CD95) receptor molecules on target cells [1]. Ligation of Fas receptors by FasL usually triggers apoptotic death of the cells expressing Fas receptors [2].

Recent studies have supported a role for Fas-FasL interactions in autoimmune beta-cell destruction. Notably, Fas expression was detected only on beta cells in pancreatic sections from two children with recent-onset Type I diabetes and apoptosis was detected in $\mathrm{Fas}^{+}$beta cells located close to $\mathrm{FasL}^{+} \mathrm{T}$ cells infiltrating the islets [3]. Interleukin (IL) $-1 \beta$ induces Fas on mouse [4] and human [5] beta cells in vitro and IL-1-sensitized Fas-expressing islet cells are killed by addition of anti-Fas monoclonal antibody [4]. Also, apoptosis was reported to be the mode of betacell death in non-obese diabetic (NOD) mice that de- 
veloped diabetes [6]. In another study in NOD mice, FasL was detected on $\mathrm{CD}^{+}$and $\mathrm{CD} 8^{+} \mathrm{T}$ cells and Fas expression was detected on beta cells in syngeneic islet grafts undergoing autoimmune destruction; also, Fas expression correlated with expression of the proinflammatory cytokines, IL-1 alpha (IL-1 $\alpha$ ), tumour necrosis factor alpha (TNF- $\alpha$ ) and interferon gamma (IFN- $\gamma)$ in the islet grafts [7]. In contrast, upregulation of Fas expression on the majority of NOD mouse beta cells did not correlate with the onset of autoimmune diabetes in another study. Expression of Fas on a small number of beta cells suggested, however, that some Fas-mediated destruction can occur [8].

Reports that NOD mice lacking Fas (NOD-lpr/lpr mice created by crossing NOD mice with MRL-lpr/ $l p r$ mice that have an incapacitating mutation in the fas gene) do not develop diabetes and are resistant to adoptive transfer of diabetes $[9,10]$ suggested that Fas expression by beta cells is necessary for their destruction during the course of the insulitis process. Subsequent studies suggested that the failure of diabetes development in Fas-deficient NOD-lpr/lpr mice could, however, be due to immune defects in the $l p r$ mouse other than Fas deletion [11-13]. The possibility that the abnormal immune phenotype of NOD-lpr/lpr mice could complicate interpretation of results was circumvented in two newly derived mouse strains in which FasL and Fas gene expressions were deleted, and still diabetes was prevented [14]. In addition, diabetes was prevented when Fas expression was abrogated in transgenic NOD mice with $\mathrm{CD} 4^{+} \mathrm{T}$ cells bearing highly diabetogenic beta-cell specific $\mathrm{T}$ cell receptors [15]. Also, activation of beta-cell cytotoxic $\mathrm{CD}^{+} \mathrm{T}$ cells in $\mathrm{T}$ cell receptor transgenic NOD mice was associated with expression of FasL on the diabetogenic T cells [16].

In view of the controversial findings regarding a pathogenic role for Fas-FasL interactions in autoimmune diabetes, using genetically manipulated NOD mice, this study was initiated to find whether FasL has a pathogenic role in spontaneous autoimmune diabetes in NOD mice. We investigated the effects of a neutralizing antibody to FasL on the recurrent autoimmune response that leads to destruction of beta cells in syngeneic islet grafts transplanted into diabetic NOD mice. The results provide evidence that FasL-mediated mechanisms play a major part in islet infiltration by leucocytes and beta-cell destruction in autoimmune diabetes.

\section{Materials and methods}

Animals. Male and female NOD mice (Taconic, Germantown, N. Y., USA), aged 4 weeks, were used as islet donors and diabetic NOD mice (males and females, aged 17-22 weeks) were used as islet recipients. Diabetic mice (diabetes duration 3-6 weeks) were treated by daily subcutaneous injections of ultralente beef and pork insulin (1.0 U/100 g body weight) until the day before transplantation. All mice were cared for according to the guidelines of the Canadian Council on Animal Care.

Transplantations. Islets were isolated by collagenase digestion of the pancreas and Ficoll density gradient centrifugation and then hand picked [17]. A total of 500 freshly isolated islets (pooled from approximately four donor NOD mice) were transplanted under the left renal capsule in each diabetic NOD mouse, according to a previously described procedure [18]. Transplantation was considered successful if the non-fasting blood glucose returned to normal $(<7.0 \mathrm{mmol} / \mathrm{l})$ and remained normal for the first 4 days after transplantation. Tail vein blood glucose was monitored daily after transplantation by using an Accu-Chek IIm glucose monitore (Boehringer Mannheim, Laval, Quebec. Canada). Islet graft rejection was diagnosed by return of hyperglycaemia (blod glucose $>11.1 \mathrm{mmol} / \mathrm{l}$ ) accompanied by glucosuria and ketonuria on 2 consecutive days.

Experimental Design. Diabetic NOD mice were transplanted with NOD islets and divided into three groups. The first group was treated with a mouse anti-mouse FasL monoclonal antibody (mAB) (Kay 10, PharMingen, San Diego, Calif., USA) [19], $250 \mu \mathrm{g}$ i.p. three times a week from day 0 to 30 after transplantation; the second group was treated with the same dose of an isotype control mouse IgG2 b (PharMingen); and the third group received no treatment. We confirmed that the antiFasL antibody used, Kay $10 \mathrm{mAB}$, prevented hepatocyte apoptosis induced by concanavalin A (Sigma, St. Louis, Mo., USA), $15 \mathrm{mg} / \mathrm{kg}$ injected i.v. $30 \mathrm{~min}$ after the anti-FasL antibody was given to NOD mice, as reported previously [11]. In the first study, we compared the effects of anti-FasL mAB, control $\mathrm{mAB}$ and no treatment on the survival of the islet grafts. The mice were monitored daily by blood glucose measurements for 30 days after islet transplantation and the day of diabetes recurrence defined the duration of islet graft survival. In the second study, islet grafts were examined histologically and graft-infiltrating leucocytes were analysed by cytochemical staining and by immunohistochemistry at 8-14 days after transplantation. In the third study, islet grafts were removed at 6 days after transplantation and leucocytes and beta cells in the grafts were examined for apoptotic events. In the fourth study, islet grafts were removed at 8-14 days after transplantation and RNA was extracted from the grafts to measure mRNA expression of IL- $1 \alpha$, TNF- $\alpha$ and IFN- $\gamma$ by PCR assay.

Histological studies. Grafts were fixed in $10 \%$ buffered formalin, embedded in paraffin, sectioned at $4.5 \mu \mathrm{m}$, then stained with an anti-insulin antibody (Dako, Carpenteria, Calif., USA) using an immunoperoxidase technique and counterstained with haematoxylin. Coded slides were examined by light microscopy (Labophot-2, Nikon, Mississauga, Ontario, Canada).

Islet graft cell preparations. Islet grafts were removed from the renal subcapsular transplant site and processed separately from each mouse. Grafts were placed in RPMI 1640 medium supplemented with $10 \%$ heat-inactivated fetal calf serum (Life Technologies, Burlington, Ontario, Canada) and kept on ice, then transferred into Eppendorf tubes containing $500 \mu \mathrm{Ca}^{2+} /$ $\mathrm{Mg}^{2+}$-free PBS with $0.2 \mathrm{mg} / \mathrm{ml}$ EDTA (cell dissociation buffer) (Life Technologies). While on ice, the grafts were cut into small pieces with fine scissors and disrupted mechanically by syringe injection though progressively narrower gauge needles. The resulting tissue fragments were dissociated into single cells by incubation in the cell dissociation buffer at $37^{\circ} \mathrm{C}$ for $20 \mathrm{~min}$. 
Cytochemical stainings. Differential leucocyte staining of cells isolated from islet grafts was done by the buffered-differential Wright-Giemsa cytochemical stain technique (Baxter, McGaw Park, Ill., USA). Further identification of neutrophils was done by using a naphthol AS-D chloroacetate stain for specific esterase (Sigma) to exclude lymphocytes [20] and fluoride inhibition to exclude esterase-positive monocytes [21].

Immunohistochemical studies. Immunohistochemical staining of cells isolated from islet grafts was done to identify and quantify total leucocytes $\left(\mathrm{CD} 45^{+}\right)$and subsets of $\mathrm{T}$ cells $\left(\mathrm{CD}^{+}\right.$and $\left.\mathrm{CD}^{+}\right)$, B cells and macrophages infiltrating islet grafts. The cells were fixed in $4 \%$ paraformaldehyde in PBS for $30 \mathrm{~min}$ at room temperature and washed twice in PBS by centrifugation at $400 \mathrm{~g}$ for $5 \mathrm{~min}$ at $4{ }^{\circ} \mathrm{C}$. The fixed cells $\left(2 \times 10^{4}\right.$ in $\left.10 \mu \mathrm{l}\right)$ were placed on glass slides coated with 3 -aminopropyltriethoxysilane (Sigma) and the slides were stored at $-86^{\circ} \mathrm{C}$ until processed. Slides were thawed and all subsequent incubations were done in a humidity chamber to prevent drying of the cells. First, cells attached to the slides were treated with $1 \%$ paraformaldehyde in PBS for $10 \mathrm{~min}$ at $4{ }^{\circ} \mathrm{C}$. Cells were then incubated for $3 \mathrm{~h}$ at $25^{\circ} \mathrm{C}$ in PBS containing $10 \%$ normal goat serum with $3 \%$ bovine serum albumin to block non-specific binding of secondary antibody. Next, cells were incubated for $2 \mathrm{~h}$ at $4{ }^{\circ} \mathrm{C}$ with the following rat mABs to mouse leucocyte subsets: Ly-5/T200 (CD45), L3T4 (CD4), Lyt-2 (CD8), Ly-5/B220 (B cell) and M1/70 (Mac-1) (Cedarlane, Hornby, Ontario, Canada) or rat IgG control antibody, $10 \mu \mathrm{g} /$ $\mathrm{ml}$. Cells were then washed in PBS for $30 \mathrm{~min}$ and incubated for $20 \mathrm{~min}$ at $25^{\circ} \mathrm{C}$ with a secondary antibody, biotinylated goat anti-rat mouse-absorbed IgG (Cedarlane), diluted 1:50 in PBS. Next, cells were washed in PBS, incubated with streptavidin-alkaline phosphatase conjugate (Zymed Laboratories, South San Francisco, Calif., USA) for $15 \mathrm{~min}$ at $25^{\circ} \mathrm{C}$, washed in PBS and incubated with alkaline phosphatase Fast-blue (Vector Laboratories, Burlingame, Calif., USA) diluted 1:2 in TRIS-HCl buffer, pH 9.5 for 3-5 min until staining (blue) of cell surface antigens (CD45, CD4, CD8, B-220, Mac-1) reached maximum intensity. Slides were sealed with Crystal/ Mount followed by Clariøn mounting medium (Biømeda, Foster City, Calif., USA). Cell preparations were stained in duplicate with each test or control antibody and 3000 cells were scored blindly by two independent observers who each scanned 60 different microscopic fields (oil immersion, $100 \times$ ) (Labophot-2, Nikon).

Apoptosis studies. Early during apoptosis phosphatidylserine translocates from the inner to the outer plasma membrane of the cell and exposure of phosphatidylserine on the outer surface of the cell is detected by the binding of annexin $\mathrm{V}$ to the cell surface [22]. Islet graft cells undergoing apoptosis were identified by using an annexin $\mathrm{V}$-fluorescein isothiocyanate (FITC) apoptosis detection kit (PharMingen). Cells $\left(5 \times 10^{4}\right)$ were incubated in $100 \mu \mathrm{l}$ annexin-binding buffer for $45 \mathrm{~min}$ at $4{ }^{\circ} \mathrm{C}$ in Eppendorf tubes, then $1 \mu \mathrm{l}$ of annexin V-FITC (final concentration $0.25 \mu \mathrm{g} / \mathrm{ml}$ ) was added to the cell suspension and the incubation was continued for $30 \mathrm{~min}$ in the dark at $4{ }^{\circ} \mathrm{C}$. All subsequent incubations were done in the dark. The cells were then washed in PBS, fixed in $4 \%$ paraformaldehyde in PBS for $30 \mathrm{~min}$ at room temperature and washed in PBS. The fixed cells were placed on glass slides coated with 3-aminopropyltriethoxysilane (Sigma) and stained by immunohistochemical methods to identify apoptotic cells as leucocytes or beta cells. Leucocytes were stained with a rat mAB to mouse CD45 antigen or rat IgG control antibody using an immunoenzymatic method as described (see Immunohistochemical studies). Beta cells were stained by incubation for $2 \mathrm{~h}$ at $4{ }^{\circ} \mathrm{C}$ with guinea-pig anti-insulin antibody (Linco Research, St. Louis, Mo., USA) or control guinea-pig antibody, diluted 1:1000 in PBS. Next, cells were washed in PBS, then incubated for $20 \mathrm{~min}$ at $25^{\circ} \mathrm{C}$ with biotinylated goat anti-guinea-pig Ig ( $\mathrm{Zy}-$ med), diluted 1:200 in PBS. This was followed by incubation for $15 \mathrm{~min}$ at $25^{\circ} \mathrm{C}$ with streptavidin-alkaline phosphatase conjugate (Zymed), washing in PBS and incubation with 5-bromo4-chloro-3-indolyl phosphate/nitrobluetetrazolium chromogen (Biømeda) diluted 1:2 in TRIS-HCl buffer, $\mathrm{pH} 9.5$ for 7-10 min until staining (blue) of intracellular insulin reached maximum intensity. Slides were sealed with Crystal/Mount and Clariøn mounting medium (Biømeda). Stained cells were identified microscopically by using an inverted microscope with epi-fluorescence and brightfield attachments (Diaphot 300, Nikon). Apoptotic beta cells stained green by fluorescence microscopy (annexinV-FITC ${ }^{+}$) and blue intracellularly by brightfield microscopy (insulin ${ }^{+}$). Apoptotic leucocytes stained green by fluorescence microscopy (annexinV-FITC ${ }^{+}$) and blue on the cell surface by brightfield microscopy $\left(\mathrm{CD}^{2} 5^{+}\right)$. Cell preparations were stained in duplicate with each test or control antibody and 3000 cells were scored blindly by two independent observers who each scanned 60 different microscopic fields (oil immersion, $60 \times$ ).

Annexin V-FITC staining to detect apoptotic cells was validated as follows. Thymocytes $\left(2 \times 10^{6} / \mathrm{ml}\right)$ were prepared from 9-day-old NOD mice and activated with anti-CD3 mAB (145-2C11, PharMingen), $2 \mu \mathrm{g} / \mathrm{ml}$ in PBS for $24 \mathrm{~h}$, then incubated on plates coated with hamster anti-mouse Fas mAB (Jo-2, PharMingen) or hamster control IgG2 a (PharMingen), $2 \mu \mathrm{g} / \mathrm{ml}$ in PBS for $8 \mathrm{~h}$. Anti-CD3 mAB-activated thymocytes incubated with control antibody were $3 \pm 1 \%$ annexin $\mathrm{V}$ FITC $^{+}$, whereas those incubated with anti-Fas $\mathrm{mAB}$ were $86 \pm 4 \%$ annexin V-FITC ${ }^{+}$and served as positive controls for annexin V-FITC staining of islet graft cells in each staining run.

PCR analyses. RNA was extracted from islet grafts by a modification of the guanidinium thiocyanate method [23] and cytokine mRNA transcripts were measured in a semi-quantitative RT-PCR assay as described previously [24]. The synthesis of cDNA was carried out on $5 \mu \mathrm{g}$ of total RNA with a Superscript Reverse-Transcriptase Kit (Life Technologies), using oligo (deoxythymidine) $)_{12-18}$ and Moloney murine leukemia virus reverse transcriptase $(20 \mathrm{U})$ in a $25-\mu \mathrm{l}$ volume at $37^{\circ} \mathrm{C}$ for $1.5 \mathrm{~h}$. The reverse transcription product was diluted 1:20, 1:100, and 1:500 in sterile $\mathrm{H}_{2} \mathrm{O}$. The PCR amplification of cDNA was done on $5 \mu \mathrm{l}$ of each dilution in a $20-\mu$ l volume containing $80 \mathrm{ng}$ of each primer, $0.25 \mathrm{mmol} / \mathrm{l}$ of each deoxyribonucleoside triphosphate, $92.5 \mathrm{KBq}$ of $\left[\alpha_{-}{ }^{32} \mathrm{P}\right]$ deoxycytidine triphosphate $111 \mathrm{MBq} / \mathrm{nmol}$, Du Pont, Mississauga, Ontario, Canada), $2 \mathrm{U}$ of AmpliTaq (Perkin Elmer Cetus, Norwalk, Conn., USA) and $3 \mathrm{mmol} / \mathrm{l} \mathrm{Mg}^{2+}$. Samples were amplified through $40 \mathrm{cy}-$ cles at $94^{\circ} \mathrm{C}$ for $20 \mathrm{~s}, 60^{\circ} \mathrm{C}$ for $20 \mathrm{~s}$, and $72{ }^{\circ} \mathrm{C}$ for $30 \mathrm{~s}$ in a Gene Amp PCR System 9600 (Perkin Elmer Cetus). The sequences of the sense and antisense oligonucleotide primers, respectively, were as follows: IL-1 $\alpha$ : CGTCAGGCAGAAGTTTGTCA and TGATGAGTTTTGGTGTTTCTGG; TNF- $\alpha$ : CTTAGACTTTGCGGAGTCCG and ACAGTCCAGGTCACTGTCCC; IFN- $\gamma$ : CGCTACACACTGCATCTTGG and GGCTGGATTCCGGCAACA; cyclophilin: GACAGCAGAAAACTTTCGTGC and TCCAGCCACTCAGTCTTGG. The PCR reaction products were electrophoresed on $1.5 \%$ agarose gels and transferred to nylon membranes. Incorporation of ${ }^{32} \mathrm{P}$ in the PCR product bands was measured by phosphor imager analysis (Fujix BAS 1000, Fuji Photo Film, Tokyo) and expressed as photon-stimulated luminescence per minute. Each cytokine signal was normalized to the cyclophilin signal 


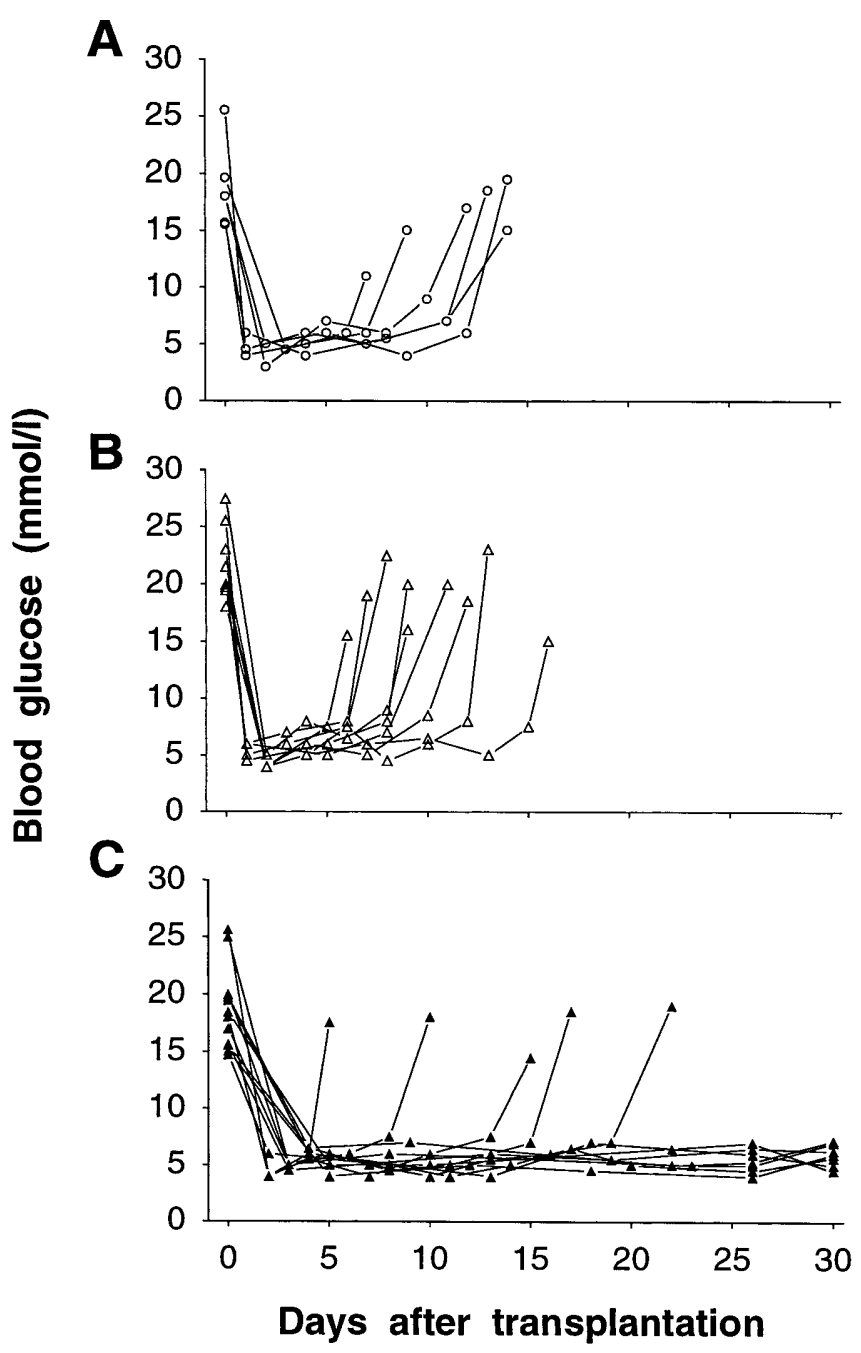

Fig.1A-C. Blood glucose values in individual diabetic NOD mice before (day 0) and for 30 days after transplantation of 500 syngeneic islets under the left renal capsule. The mice received islets only $(\mathbf{A}, \bigcirc, n=6)$, islets and a control $\mathrm{mAB}(\mathbf{B}$, $\Delta, n=9)$, and islets plus an anti-mouse FasL mAB, $250 \mu \mathrm{g}$ i.p. three times a week from day 0 to 30 after transplantation $(\mathbf{C}$, $\boldsymbol{\Delta}, n=12)$. Islet graft destruction is indicated by recurrence of hyperglycaemia (blood glucose $>11.1 \mathrm{mmol} / \mathrm{l}$ )

of the same sample. All samples compared were amplified in the same PCR run to avoid inter-assay variation and the final results are the averages from two separate PCR assays.

Statistical analysis. Data are presented as means \pm SEM and statistical comparisons were made by Welch's unpaired $t$ test, with a two-tailed $p$ value less than 0.05 considered statistically significant.

\section{Results}

Effects of anti-FasL antibody on islet graft survival. Syngeneic islet grafts restored normoglycaemia (blood glucose $<7.0 \mathrm{mmol} / \mathrm{l}$ ) in diabetic NOD mice 8-12 h after transplantation. Diabetes recurred, however, (blood glucose $>11.1 \mathrm{mmol} / \mathrm{l}$ ) between day 7

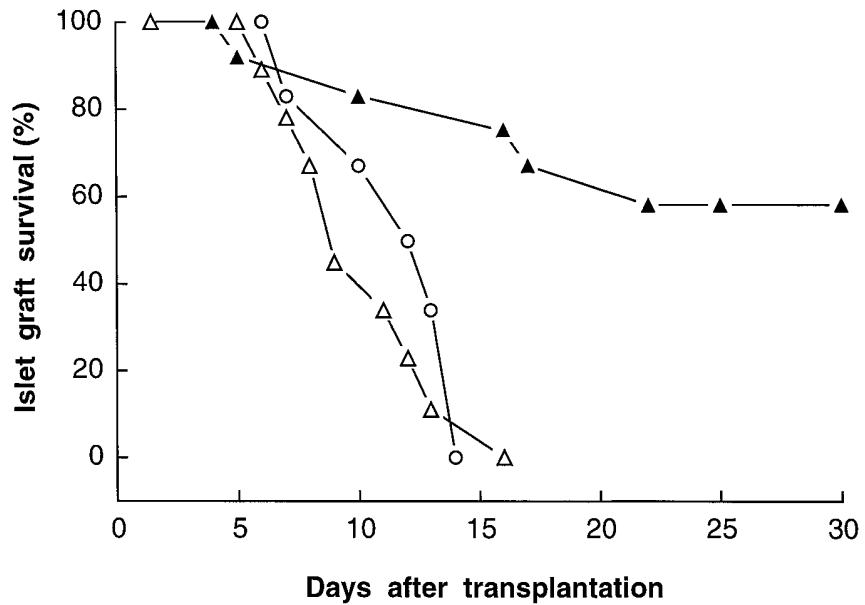

Fig. 2. Anti-FasL antibody treatment prolongs survival of syngeneic islet grafts in NOD mice. Graft survival was measured by the blood glucose concentrations shown in Figure 1. Islet grafts survived and maintained normoglycaemia for 30 days in $58 \%$ ( 7 of 12) of the mice treated with anti-FasL mAB (A) compared with none ( 0 of 9$)$ of the mice treated with a control $\mathrm{mAB}$ $(\Delta)$ and none $(0$ of 6$)$ of the mice that received islets only $(\bigcirc)$

and 14 after transplantation. In contrast, treatment of islet-transplanted NOD mice with anti-FasL $\mathrm{mAB}$ maintained normoglycaemia for 30 days in 7 of 12 mice $(58 \%)$ compared with none of 9 mice treated with a control mAB (Fig.1). Median graft survival was 12 days for NOD mice that received islets only, 9 days for mice that received islets and a control $\mathrm{mAB}$, and $>30$ days for mice that received islets and anti-FasL mAB (Fig. 2).

Histology of islet grafts. At 12 days after islet transplantation, there was extensive leucocytic infiltration of islet grafts in mice treated with a control $\mathrm{mAB}$; furthermore, there was a great reduction of beta cells in islet grafts of control $\mathrm{mAB}$-treated mice that became diabetic (Fig.3). In contrast, leucocytic infiltration was less and abundant beta cells were found in islet grafts of mice treated with anti-FasL $m A B$ at 12 days (Fig. 3 ) and at 30 days after transplantation.

Leucocyte subsets in islet grafts. Anti-FasL mAB significantly decreased the number of leucocytes $\left(\mathrm{CD} 45^{+}\right.$cells $)$that infiltrated islet grafts and the effect was greatest in mice in which beta cells in islet grafts were preserved and normoglycaemia was maintained (Fig. 4). Reductions in leucocytic infiltration of islet grafts resulting from anti-FasL $\mathrm{mAB}$ treatment affected all leucocyte subsets identified by cytochemical staining; lymphocytes, monocytes and neutrophils (no eosinophils or basophils were found). Also affected were all leucocyte subsets identified by immunohistochemical staining $-\mathrm{T}$ cells $\left(\mathrm{CD}^{+}\right.$and $\left.\mathrm{CD} 8^{+}\right)$, B cells $\left(\mathrm{B}-220^{+}\right)$, macrophages $\left(\mathrm{Mac}-1^{+}\right)$and esterase-containing neutrophils (esterase ${ }^{+}$) (Fig. 4). 


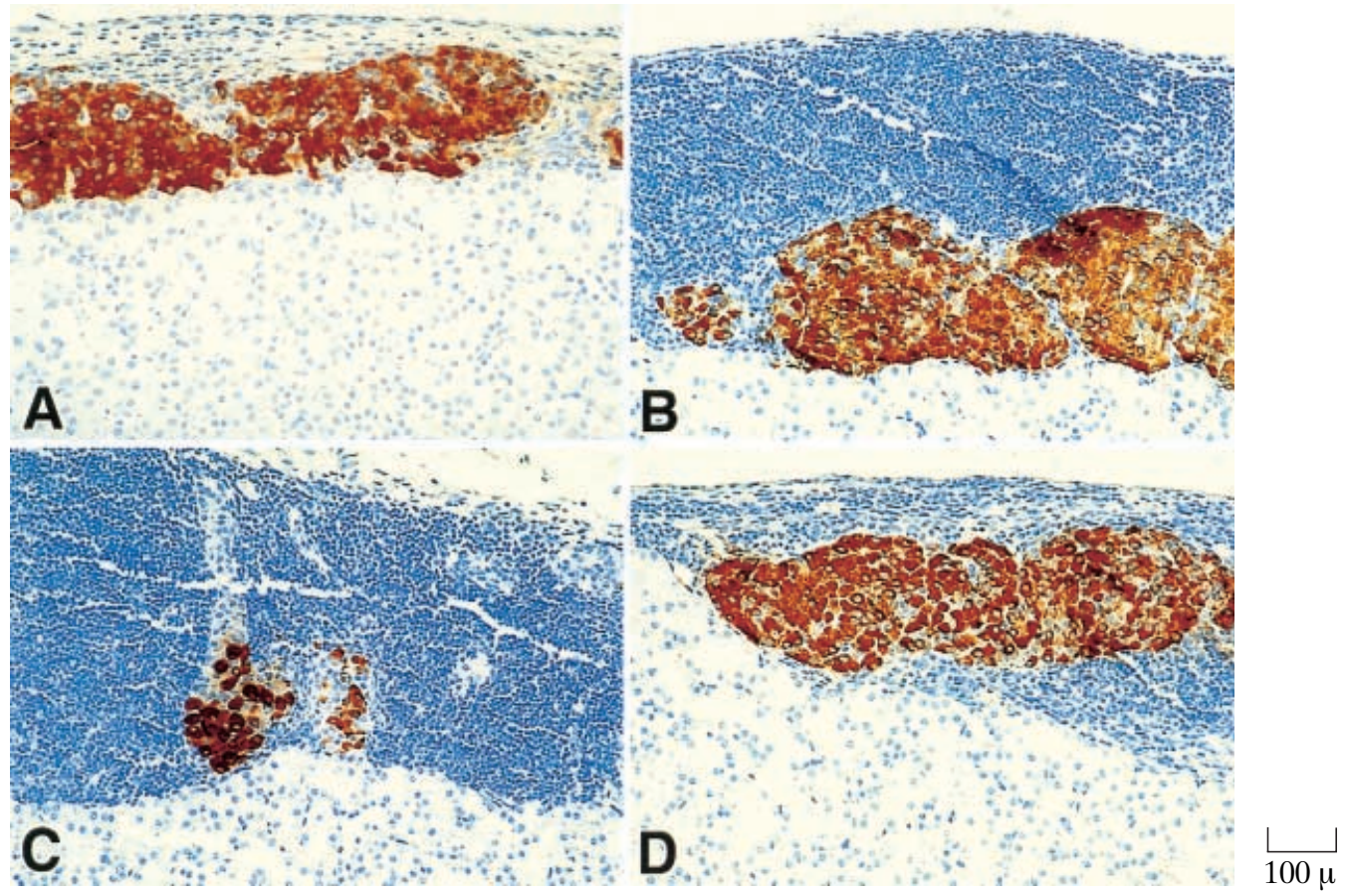

Fig.3 A-D. Photomicrographs of syngeneic islet grafts transplanted under the left renal capsule in diabetic NOD mice. At $6 \mathrm{~h}$ after islet transplantation, abundant beta cells (stained brown with anti-insulin antibody) were detected in an islet graft placed under the renal capsule and overlying the kidney (A). At 12 days after islet transplantation, many leucocytes (small cells with blue-staining nuclei) had infiltrated the renal subcapsular space overlying the islet graft in a control $\mathrm{mAB}$ treated mouse that was normoglycaemic (B). Also, many leucocytes infiltrated the islet graft and few beta cells remained in a control $\mathrm{mAB}$-treated mouse that was diabetic $(\mathbf{C})$. In contrast, leucocytic infiltration was less and the beta-cell mass of the islet graft was preserved at 12 days after transplantation in a mouse treated with anti-FasL mAB (D).

Apoptosis in islet grafts. In addition to significantly decreasing leucocytic infiltration and preserving beta cells in islet grafts, anti-FasL mAB significantly decreased the frequency of apoptotic events in beta cells (from $9.0 \pm 0.7 \%$ to $1.1 \pm 0.8 \%$ ) at 6 days after islet transplantation (Fig. 5). In contrast, apoptosis in leucocytes was similar ( $\sim 15-20 \%$ of CD $45^{+}$cells $)$in islet grafts of anti-FasL and control mAB-treated mice (Fig. 5).

Cytokines expressed in islet grafts. The mRNA expressions of the proinflammatory cytokines, IL-1 $\alpha$, TNF- $\alpha$ and IFN- $\gamma$ were not significantly different in islet grafts of NOD mice treated with anti-FasL and control mABs (Fig. 6).

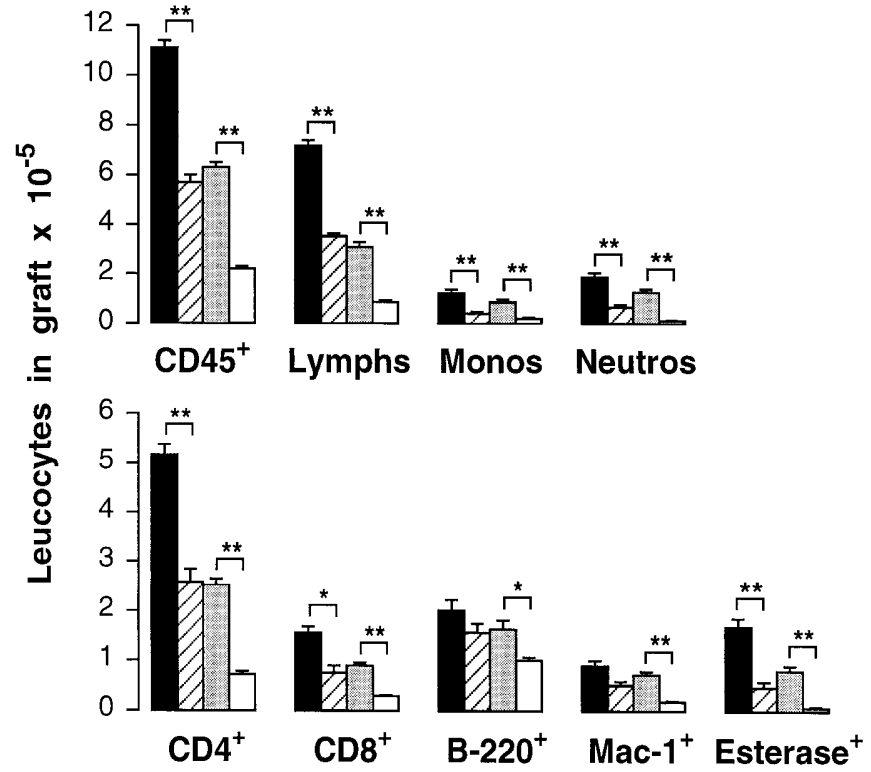

Fig.4. Leucocyte subsets in islet grafts of NOD mice transplanted with syngeneic islets and treated with either an antiFasL $\mathrm{mAB}$ or a control $\mathrm{mAB}$. At 8-14 days after islet transplantation, total leucocytes $\left(\mathrm{CD} 45^{+}\right.$cells) and all leucocyte subsets [lymphocytes (Lymphs), monocytes (Monos) and neutrophils (Neutros)], including T cells $\left(\mathrm{CD}^{+}\right.$and $\left.\mathrm{CD}^{+}\right)$, B-cells $\left(\mathrm{B}-220^{+}\right)$, macrophages $\left(\mathrm{Mac}-1^{+}\right)$and neutrophils $\left(\right.$esterase $\left.^{+}\right)$ were decreased in islet grafts of mice treated with anti-FasL $\mathrm{mAB}$ compared with those treated with control $\mathrm{mAB}$. Values are means \pm SEM. ${ }^{*} p<0.05, * * p<0.01$ for anti-FasL mABtreated diabetic mice $(\mathbb{Z}, n=3)$ vs control mAB-treated diabetic mice $(\boldsymbol{\square}, n=6)$ and for anti-FasL mAB-treated normoglycaemic mice $(\square, n=7)$ vs control mAB-treated normoglycaemic mice $(\square, n=6)$ 

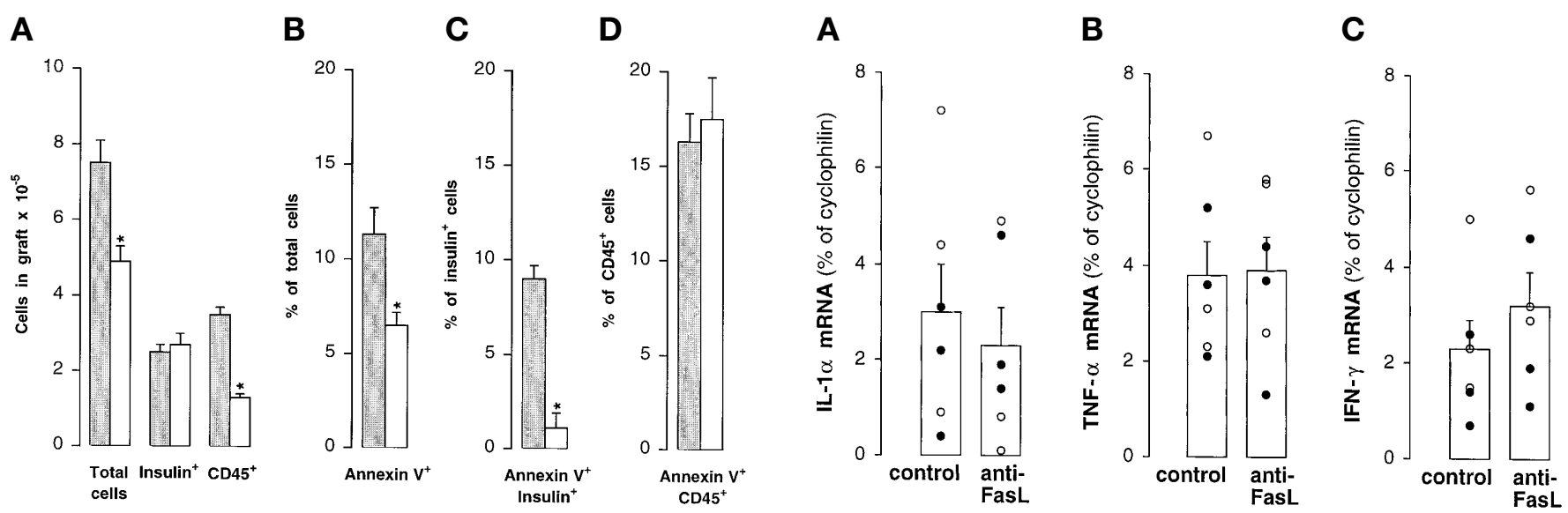

Fig.5 A-D. Anti-FasL antibody decreases leucocytic infiltration and beta-cell apoptosis in syngeneic islet grafts transplanted into diabetic NOD mice. Islet grafts in mice treated with control mAB $(\square, n=6)$ and anti-FasL mAB $(\square, n=6)$ were examined in normoglycaemic mice at 6 days after islet transplantation. A total cells, beta cells (insulin ${ }^{+}$) and leucocytes $\left(\mathrm{CD} 45^{+}\right)$in islet grafts, B per cent of total islet graft cells that were apoptotic (Annexin $\mathrm{V}^{+}$), $\mathbf{C}$ per cent of beta cells that were apoptotic (Annexin $\mathrm{V}^{+}$insulin ${ }^{+}$), D per cent of leucocytes that were apoptotic $\left(\right.$ Annexin $\mathrm{V}^{+} \mathrm{CD} 45^{+}$). Values are means \pm SEM. ${ }^{*} p<0.01$ vs

\section{Discussion}

Recent studies have either supported or denied a role for Fas-FasL interactions in the development of autoimmune diabetes. In this study, we used a neutralizing monoclonal antibody to FasL to directly address the question of whether Fas-FasL interactions participate in autoimmune beta-cell destruction. We found that anti-FasL antibody significantly decreased autoimmune destruction of beta cells in syngeneic islet grafts transplanted into diabetic NOD mice. Thus, $58 \%$ of mice treated with anti-FasL antibody were normoglycaemic at 30 days after islet transplantation compared with none of control antibody-treated mice. Although leucocytic infiltration of the islet grafts still occurred in mice treated with anti-FasL antibody, this was significantly less than in mice treated with control antibody. These findings indicate that islet infiltration by leucocytes and beta-cell destruction in autoimmune diabetes in NOD mice involves FasLmediated mechanisms.

In another study, the authors concluded that Fas plays only a minor part in beta-cell death in NOD mice because NOD islet grafts lacking Fas expression (from NOD-lpr/lpr mice) were protected only marginally from autoimmune destruction when grafted into diabetic NOD mice [12]. In the latter study the NOD or NOD/lpr (Fas deficient) fetal pancreas grafts transplanted into diabetic NOD mice did, however, not reverse diabetes [12], whereas we transplanted a mass of islets isolated from NOD mice sufficient to reverse diabetes and, in this setting, we ob-

Fig. 6A-C. Proinflammatory cytokines, IL-1 $\alpha$ (A), TNF- $\alpha$ (B) and IFN- $\gamma(\mathbf{C})$ are expressed at similar levels in syngeneic islet grafts of NOD mice treated with anti-FasL and control mABs. Islet grafts were harvested at 8-14 days after transplantation and cytokine mRNA expressions were determined by reverse transcriptase PCR assay. Cytokine mRNA expressions are given as percentages of cyclophilin mRNA. Mean values \pm SEM are shown for the groups of mice treated with control and anti-FasL mABs and for individual normoglycaemic $(O)$ and diabetic (O) mice

served that FasL neutralization significantly decreased leucocytic infiltration of islet grafts and prevented beta-cell destruction and diabetes recurrence. Therefore, we conclude that both studies ([12] and this study) provide evidence that Fas-FasL interactions are involved in autoimmune beta-cell destruction; the experimental approach used in our study suggests that FasL has a major pathogenic role.

Interestingly, the anti-FasL antibody that prevented leucocytic infiltration of islets and beta-cell destruction in our study failed to prevent autoimmune destruction of beta cells elicited by cyclophosphamide and adoptive transfer of diabetogenic splenocytes in NOD mice in another study [11]. Taken together, these findings suggest that FasL is involved in the initiation phase of insulitis because this is elicited by islet transplantation but not by cyclophosphamide and adoptive transfer of diabetogenic cells, procedures that bypass the initiation phase. Similarly, FasL appeared in the pancreas of NOD mice during insulitis onset [25] but was not detected in the pancreas after adoptive transfer of NOD splenocytes into immunodeficient (scid/scid) mice [26]. Further evidence that FasL plays a part in initiating insulitis was provided by a recent report that anti-FasL antibody prevented insulitis and diabetes development when given to pre-insulitic (2-week-old) but not to post-insulitic (5-week-old) NOD mice [27]. Similarly, we found that anti-FasL antibody significantly decreased islet infiltration by leucocytes; furthermore, beta-cell destruction and diabetes were prevented only when leucocytic infiltration was greatly reduced by the anti-FasL antibody. This suggests that FasL plays an 
important part in recruiting leucocytes into the islets, both in pancreatic insulitis development in natural course autoimmune diabetes in NOD mice and in recurrent autoimmune diabetes after syngeneic islet transplantation.

Both cell membrane-bound FasL [28] and soluble FasL cleaved from membrane-bound FasL by a tissue metalloproteinase $[29,30]$ exhibit potent chemoattractant activity for human and mouse neutrophils. The molecular mechanism(s) governing FasL-dependent chemotactic activity are not known. One study suggested that the chemoattractant activity of soluble FasL was mediated by ligation of Fas on neutrophils and activation of a new signalling function, independent of the Fas death domain-mediated apoptosis of these cells [29]. In another study, FasL was reported to induce the processing and release of IL- $1 \beta$ from mouse peritoneal macrophages and IL- $1 \beta$ was found to be responsible for the neutrophilic infiltration [28]. These proinflammatory effects of FasL could explain the neutrophilic infiltration and destruction of islet grafts observed when mouse islet beta cells were engineered to express FasL, either transgenically $[31,32]$ or by gene transfection [32, 33]. Also, we recently reported that FasL expression by testicular Sertoli cells co-transplanted with syngeneic islets in NOD mice was associated with neutrophilic leucocyte infiltration and destruction of the islet graft [34]. Our finding that FasL neutralization significantly reduced islet infiltration by neutrophils and prevented beta-cell destruction in the present study suggests that FasL-dependent neutrophil recruitment contributed to islet beta-cell destruction.

In addition to significantly decreasing leucocytic infiltration and preserving beta cells in islet grafts, anti-FasL antibody significantly decreased apoptosis of beta cells in the islet grafts. The latter finding is consistent with our previous report that FasL is expressed on $\mathrm{CD}^{+}$and $\mathrm{CD} 8^{+} \mathrm{T}$ cells that infiltrate syngeneic islet grafts in NOD mice and that beta cell destruction correlates with Fas receptor expression on beta cells in the islet grafts [7]. Therefore, by blocking FasL on islet-infiltrating T cells from interacting with Fas on beta cells, anti-FasL antibody would be expected to prevent beta-cell apoptosis, as we observed in the present study.

Although significantly fewer macrophages and $\mathrm{T}$ cells infiltrated islet grafts after anti-FasL antibody treatment, expression of proinflammatory cytokines (IL- $1 \alpha$, TNF- $\alpha$ and IFN- $\gamma$ ) by the islet-infiltrating cells was not decreased. This could explain why antiFasL antibody did not provide complete protection against beta-cell destruction ( $\sim 40 \%$ of islet grafts were destroyed despite anti-FasL antibody treatment). Thus, proinflammatory cytokines could still activate mechanisms of beta-cell destruction other than those mediated by FasL; for example, IL-1 and TNF- $\alpha$-mediated cytotoxic effects on beta cells and
IFN- $\gamma$-induced activation of perforin and granzyme production by cytotoxic lymphocytes. Notably, autoreactive $\mathrm{CD}^{+}$T-cells were reported to lead to islet beta-cell destruction by either the FasL-Fas or perforin pathway [35] and the authors of this study suggested that, in the NOD mouse, the FasL-Fas pathway contributes predominantly in the early stages of autoimmunity, whereas perforin-mediated beta-cell destruction might dominate in the later stages.

We have used a monoclonal antibody to FasL and shown that FasL-mediated mechanisms are involved in the development of insulitis, beta-cell apoptosis and recurrent autoimmune diabetes after syngeneic islet transplantation in NOD mice. Given the findings that Fas-FasL interactions could also have a pathogenic role in human Type I diabetes $[3,36]$, our study suggests that FasL neutralization has clinical application for prevention of Type I diabetes development or disease recurrence after islet transplantation.

Acknowledgements. This work was supported by grants from the Medical Research Council of Canada, the Canadian Diabetes Association, the Muttart Diabetes Research and Training Centre at the University of Alberta and the MacLachlan Fund of the University of Alberta Hospitals. A. Rabinovitch is a Medical Scientist of the Alberta Heritage Foundation for Medical Research. The authors thank A. Neil for assistance with immunohistochemical assays, $\mathrm{A}$. Fu for assistance with PCR assays, D. Dixon for assistance with islet transplantations and T.W. Turner for preparing the photomicrographs.

\section{References}

1. Kägi D, Vignaux F, Ledermann B et al. (1994) Fas and perforin pathways as major mechanisms of T cell-mediated cytotoxicity. Science 265: 528-530

2. Nagata S, Golstein P (1995) The Fas death factor. Science 267: 1449-1456

3. Stassi G, De Maria R, Trucco G, et al. (1997) Nitric oxide primes pancreatic $\beta$ cells for Fas-mediated destruction in insulin-dependent diabetes mellitus. J Exp Med 186: 1193-1200

4. Yamada K, Takane-Gyotoku N, Yuan X, Ichikawa F, Inada C, Nonaka K (1996) Mouse islet lysis mediated by interleukin-1-induced Fas. Diabetologia 39: 1306-1312

5. Stassi G, Todaro M, Richiusa P et al. (1995) Expression of apoptosis-inducing CD95 (Fas/Apo-1) on human $\beta$-cells sorted by flow-cytometry and cultured in vitro. Transplant Proc 27: 3271-3275

6. O'Brien BA, Harmon BV, Cameron DP, Allan DJ (1997) Apoptosis in the mode of $\beta$-cell death responsible for the development of IDDM in the nonobese diabetic (NOD) mouse. Diabetes 46: 750-757

7. Suarez-Pinzon W, Sorensen O, Bleackley RC, Elliott JF, Rajotte RV, Rabinovitch A (1999) $\beta$-cell destruction in NOD mice correlates with Fas (CD95) expression on $\beta$ cells and proinflammatory cytokine expression in islets. Diabetes 48: 21-28

8. Thomas HE, Darwiche R, Corbett JA, Kay TW (1999) Evidence that $\beta$ cell death in the nonobese diabetic mouse is Fas independent. J Immunol 163: 1562-1569 
9. Chervonsky AV, Wang Y, Wong FS et al. (1997) The role of Fas in autoimmune diabetes. Cell 89: 17-24

10. Itoh N, Imagawa A, Hanafusa T et al. (1997) Requirement of Fas for the development of autoimmune diabetes in nonobese diabetic mice. J Exp Med 186: 613-618

11. Kim Y-H, Kim S, Kim K-A et al. (1999) Apoptosis of pancreatic $\beta$-cells detected in accelerated diabetes of NOD mice: no role of Fas-Fas ligand interaction in autoimmune diabetes. Eur J Immunol 29: 455-465

12. Allison J, Strasser A (1998) Mechanisms of $\beta$ cell death in diabetes: A minor role for CD95. Proc Natl Acad Sci USA 95: 13818-13822

13. Kim S, Kim KA, Hwang DY et al. (2000) Inhibition of autoimmune diabetes by Fas ligand: The paradox is solved. J Immunol 164: 2931-2936

14. Su X, Hu Q, Kristan JM (2000) Significant role for Fas in the pathogenesis of autoimmune diabetes. J Immunol 164: 2523-2532

15. Amrani A, Verdaguer J, Thiessen S, Bou S, Santamaria P (2000) IL- $1 \alpha$, IL- $1 \beta$, and IFN- $\gamma$ mark $\beta$ cells for Fas-dependent destruction by diabetogenic $\mathrm{CD} 4^{+} \mathrm{T}$ lymphocytes. J Clin Invest 105: 459-468

16. Jun H-S, Santamaria P, Lim H-W, Zhang ML, Yoon J-W (1999) Absolute requirement of macrophages for the development and activation of $\beta$-cell cytotoxic $\mathrm{CD}^{+} \mathrm{T}$-cells in T-cell receptor transgenic NOD mice. Diabetes 48: 34-42

17. Gotoh M, Maki J, Kiyoizumi T, Satomi S, Monaco AP (1985) An improved method for isolation of mouse pancreatic islets. Transplantation 40: 437-438

18. Wang T, Singh B, Warnock G, Rajotte RV (1992) Prevention of recurrence of IDDM in islet-transplanted diabetic NOD mice by adjuvant immunotherapy. Diabetes 41: 114-117

19. Kayagaki N, Yamaguchi N, Nagao F et al. (1997) Polymorphism of murine Fas ligand that affects the biological activity. Proc Natl Acad Sci USA 94: 3914-3919

20. Yam LT, Li CY, Crosby WH (1971) Cytochemical identification of monocytes and granulocytes. Am J Clin Pathol 55: 283-290

21. Bennett JM, Reed CE (1975) Acute leukemia cytochemical profile: diagnostic and clinical implications. Blood Cells 1: 101-108

22. Vermes J, Haanen C, Steffens-Nakken H, Reutelingsperger C (1995) A novel assay for apoptosis: flow cytometric detection of phosphatidylserine expression on early apoptotic cells using fluorescein labelled annexin. J Immunol Methods 184: 39-51

23. Chirgwin JM, Przybyla AE, MacDonald RJ, Rutter KT (1979) Isolation of biologically active ribonucleic acid from sources enriched in ribonuclease. Biochemistry 18: 5294-5299

24. Rabinovitch A, Suarez-Pinzon WL, Sorensen O, Bleackley RC, Power RF (1995) IFN- $\gamma$ gene expression in pancreatic islet-infiltrating mononuclear cells correlates with autoimmune diabetes in nonobese diabetic mice. J Immunol 154: 4874-4882

25. Sainio-Pollanen S, Erkkila S, Alanko S, Hanninen A, Pollanen P, Simell O (1998) The role of Fas ligand in the development of insulitis in nonobese diabetic mice. Pancreas 16: 154-159

26. Sainio-Pollanen S, Liukas A, Pollanen P, Simell O (1999) The role of $\mathrm{CD}^{+}$cells, cell degeneration, and Fas ligand in insulitis after intraperitoneal transfer of NOD splenocytes. Pancreas 18: 282-293

27. Nagata M, Nakayama M, Yasuda H et al. (1999) Fas-induced apoptosis is not major effector mechanism but plays an important role in the initial phase of NOD diabetes. Diabetes 48 [Suppl 1]: A209 (Abstract)

28. Miwa K, Asano M, Horai R, Iwakura Y, Nagata S, Suda T (1998) Caspase 1-independent IL- $1 \beta$ release and inflammation induced by the apoptosis inducer Fas ligand. Nat Med 4: $1287-1292$

29. Seino K, Iwabuchi K, Kayagaki N et al. (1998) Cutting edge: Chemotactic activity of soluble Fas ligand against phagocytes. J Immunol 161: 4484-4488

30. Ottonello L, Tortolina G, Amelotti M, Dallegri F (1999) Soluble Fas ligand is chemotactic for human neutrophilic polymorphonuclear leucocytes. J Immunol 162: 3601-3606

31. Allison J, Georgiou HM, Strasser A, Vaux DL (1997) Transgenic expression of CD95 ligand on islet $\beta$ cells induces a granulocytic infiltration but does not confer immune privilege upon islet allografts. Proc Natl Acad Sci USA 94: 3943-3947

32. Kang S-M, Schneider DB, Lin Z et al. (1997) Fas ligand expression in islets of Langerhans does not confer immune privilege and instead targets them for rapid destruction. Nat Med 3: 738-743

33. Muruve DA, Nicolson AG, Manfro RC, Strom TB, Sukhatme VP, Liberman TA (1997) Adenovirus-mediated expression of Fas ligand induces hepatic apoptosis after systemic administration and apoptosis of ex vivo-infected pancreatic islet allografts and isografts. Hum Gene Ther 8: 955-963

34. Korbutt GS, Suarez-Pinzon WL, Power RF, Rajotte RV, Rabinovitch A (2000) Testicular Sertoli cells exert both protective and destructive effects on syngeneic islet grafts in non-obese diabetic mice. Diabetologia 43: 474-480

35. Kreuwel HT Morgan DJ, Krahl T, Ko A, Sarvetnick N, Sherman LA (1999) Comparing the relative role of perforin/granzyme versus Fas/Fas ligand cytotoxic pathways in $\mathrm{CD}^{+} \mathrm{T}$ cell-mediated insulin-dependent diabetes mellitus. J Immunol 163: 4335-4341

36. Moriwaki M, Itoh N, Miyagawa J et al. (1999) Fas and Fas ligand expression in inflamed islets in pancreas sections of patients with recent-onset Type 1 diabetes mellitus. Diabetologia 42: 1332-1340 